\title{
Shanghai Cooperation Organization (SCO) in Eurasia Regionalism: New India-Pakistan Membership and Regional Security
}

\author{
Raviq Ayusi \\ Master Program Student of International Relations Department at Universitas Airlangga \\ aviqa.yusi@gmail.com
}

Siti Nurhasanah

Master Program in American Regional Studies at Universitas Indonesia husna.rifa04@gmail.com

\begin{abstract}
Abstrak
Tulisan ini membahas tipologi baru dalam regionalisme saat ini yang ada di kawasan Eurasia, Shanghai Cooperation Organization (SCO). SCO adalah SCO adalah permanen organisasi internasional antar-pemerintah yang awalnya dibentuk untuk memerangi terorisme, separatisme dan ekstremisme (3T) di kawasan Eurasia. Regionalisme muncul bisanya disebabkan beberapa faktor seperti faktor geografi, kondisi sosial budaya, kerjasama ekonomi dan lain sebagainya. Berdasarkan ciri regionalisme dan adanya globalisasi, makalah ini menganalisa karakteristik khusus regionalisme dikawasan Eurasia yang diwakili oleh SCO melalui pendekatan tatakelola keamanan dan regionalisme. Karakter regionalisme SCO terlihat dari bagaimana proses keanggotaan India dan Pakistan sebagai anggota SCO pada Juni 2017 dan faktor keamanan kawasan. Tulisan ini akan diuraikan melalui tiga komponen: dinamika dan perkembangan SCO dalam menghadapi ancaman keamanan kawasan, tatakelola keamanan: bagaimana SCO melihat ancaman keamanan kawasan saat ini, dan identifikasi regionalisme melalui studi kasus perluasan keanggotaan India dan Pakistan dalam SCO.
\end{abstract}

Kata kunci: Regionaslime, Shanghai Cooperation Organization, Keamanan Regional, India, Pakistan

\section{Introduction}

The emergence of regional security cooperation cannot be separated from the importance of a region itself. Countries are related to the level of geography closeness and mutual interdependence of interests. The development and cooperation of the region further regenerate the dynamics of the development of regionalism. Especially after the cold war and the events of 9/11, the pattern of development of regionalism increasingly influenced the international order. In history, SCO (Shanghai Cooperation Organization) becomes one of the most potential regional organizations 
after the Cold War, especially in the Asian continent that was formed in 2001. SCO or the Shanghai Cooperation Organization is a regional cooperation organization that exists in the Eurasia region. The SCO organization focuses on efforts to combat $3 \mathrm{~T}$ security threats (separatism, terrorism and, extremism) in the Eurasia region.

In the field of security, regionalism seeks to create security and peace stability in which each region has different ways of responding to the threats and different perceptions in seeing threats. Every year, SCO faces a security threat that comes from $3 \mathrm{~T}$ that continues to increase in the region. Therefore, there are many skeptical views that doubt the SCO's ability to fight terrorism since it is still classified as a new regional organization. Today, the expansion of SCO's core membership has also long been a debate especially the membership of India and Pakistan that are still in dispute. However, India and Pakistan are located in the South Asian region that is currently less stable. In addition, the relations between India and Pakistan with the twosuperpower countries in the SCO - are China and Russia.

However, the official membership that was finally given to India and Pakistan in 2017 and amid the increasingly alarming conditions of the Eurasia region, is important to see. SCO now has entities that are different by having members in several regions. This also shows the different characteristics of regionalism in general. Then, what are the special characteristics of Eurasia regionalism represented by SCO? This paper will provide three frameworks that will be explained. First, the dynamics and development of SCO in facing regional security threats. Second, security governance: how SCO sees current regional security threats. And third, identify regionalism through case studies of expanding the membership of India and Pakistan in SCO.

\section{The Dynamics and Development of the SCO in the Face of Regional Security}

\section{Threats}

SCO is a regional cooperation organization that was originally a discussion forum known as the Shanghai Five and was initiated by China in 1996. The initial formation was aimed at resolving state conflicts, border, ethnicity, and so on, among member countries of SCO. Finally, SCO was formed in 2001 as a regional cooperation organization with a focus on combating 3T (Separatism, Terrorism, and Extremism) to increase regional security. The SCO also fights international drugs 
trafficking that becomes source of terrorism funding. SCO members consist of China, Russia and four Central Asian countries: Kazakhstan, Kyrgyzstan, Tajikistan, and Uzbekistan. SCO also has a number of countries included in SCO's observers namely Mongolia, India, Iran, Pakistan, Afghanistan; and several SCO's dialogue partners, Belarus, Sri Lanka, and Turkey. ${ }^{1}$

SCO responds to threats through appropriate mechanisms in Shanghai Spirit, as the norm in relations between members of the SCO country. Member States exercise their rights and obligations under the convention adopted that is in accordance with the principles of equality, state territorial integrity, and nonintervention in the internal affairs of other countries. ${ }^{2}$ For example, when Kyrgyzstan was called a failed country, it experienced in a major crisis in 2005 and changed its government. SCO then held a discussion so that the situation could be stabilized and prevented from deepening the crisis. ${ }^{3}$ However the SCO also did not interfere in Kyrgyzstan's foreign policy. In this case, the SCO is similar in ASEAN security policy in supporting the Southeast Asian government against internal rebellion and communist encroachment from home and abroad. At the same time, ASEAN members agreed not to disrupt their respective internal affairs and continue to promote the stability of the member regime. ${ }^{4}$

Besides having the norm, SCO also formed a permanent body called the Regional Anti-Terrorism Structure (RATS) in 2004. The task of RATS is to establish relationships with competent institutions; prepare counterterrorism exercises; compile international legal documents against terrorism, separatism and extremism; respond to global challenges; and assist in various fields of combating terrorism, separatism and extremism. ${ }^{5}$ Through RATS, annual Peace Mission joint training is held by all members to improve their ability to fight terrorism. ${ }^{6}$ The success of RATS was

\footnotetext{
${ }^{1}$ The Shanghai Cooperation Organisation. "About SCO". http://eng.sectsco.org/about_sco/

${ }^{2}$ Xiaodong, Zhao. "The Shanghai Cooperation Organisation and Counter-Terrorism Cooperation." ASIA Paper (2012).

${ }^{3}$ Matveeva, Anna, and Antonio Giustozzi. "The SCO: A Regional Organization in The Making." Working Paper 39 (2008).

${ }^{4}$ Lanteigne, Marc. " "In Medias Res": The Development of the Shanghai Cooperation Organization as a Security Community." Pacific Affairs 79, no. 4 (2006/2007): 605-622.

5 The Shanghai Cooperation Organisation. "About SCO".

${ }^{6}$ Yuqun, Shao. "Intra-SCO Security Cooperation Helps Regional Stability." Last modified September 17, 2014. https://www.chinausfocus.com/peace-security/intra-sco-security-cooperation-helps-regionalstability
} 
demonstrated in 2006, which succeeded in identifying terrorist organizations and preventing 250 terrorist attacks in the SCO area. $^{7}$

In SCO itself, there are also two superpower countries: China and Russia. As revealed by Allison (2004) that China's presence balancing Russia's efforts to provide policy at $\mathrm{SCO}^{8}$. In some cases, China and Russia seem to limit each other's strengths and influences so that no one becomes dominant in the region ${ }^{9}$. As in 2010, China wanted to establish SCO Development Bank as a regional bank and free trade zone in the region but was rejected by Russia for fear of being under Chinese control. ${ }^{10}$ As India-Pakistan's membership in SCO could not be separated from influence China and Russia. Since its inception, Russia has supported India's membership, but China rejected it - which was marked by a desire for Pakistan to join the SCO. However, SCO officially announced that India and Pakistan were members of the SCO core in June 2017.

By India and Pakistan joining SCO means that there will be four major countries. If you look at the relations between these four countries, especially China India and from a realist perspective, China should indeed reject Indian membership in the SCO. The evidence of China's resistance was previously seen with China coercing simultaneously with Pakistan's acceptance in SCO. ${ }^{11}$ Or China has repeatedly emphasized that membership expansion must be carried out on the basis of consensus,

"We believe SCO members will decide according to their own consensus development", said a spokesman for the Chinese Ministry of Foreign Affairs ${ }^{12}$. Because of India's membership will affect the balance of Chinese influence in the SCO. Today, China sees India as the emerging of superpower country. Furthermore, India and Pakistan are still involved in the dispute. Since China eventually agreed to the membership of these two countries, means that there are certain conditions and

\footnotetext{
${ }^{7}$ Lanteigne, Marc. " "In Medias Res"

${ }^{8}$ Allison, Roy. "Regionalism, Regional Structures and Security Management in Central Asia." International Affairs 80, no. 3 (2004): 463-483.

${ }^{9}$ Mihslsche, Veronica. "Cooperation Vs. Competition in Central Asia." Challenges of the Knowledge Society Conference (2015).

${ }^{10}$ Council on Foreign Relation. "The Shanghai Cooperation Organization". Last modified October 14, 2015. https://www.cfr.org/backgrounder/shanghai-cooperation-organization

11 The Hindu. "Fresh initiatives in SCO expansion." Last modified Maret 23, 2010. http://www.thehindu.com/todays-paper/tp-opinion/Fresh-initiatives-in-SCOexpansion/article16590257.ece

${ }^{12}$ Panda, Jagannath P. "Beijing's Perspective on Expansion of the Shanghai Cooperation Organization: India, South Asia, and the Spectrum of Opportunities in China's Open Approach." Asian Perspective 36, no. 1 (2012): 493-530.
} 
factors currently different from before, being considered in entering India and Pakistan in the SCO.

\section{Security Governance: How SCO See Current Regional Security Threats}

As one of the regional cooperation organizations in the Eurasia region, SCO is a geopolitical agent of the region. So, the SCO is required to act strategically in identifying and dealing with regional threats. In this contemporary era, geopolitical warfare against threats such as transnational crime, terrorism, drug trafficking, and so on has resulted in alliances between countries. SCO as a regional geopolitical agent must be able to organize and control the area for mutual benefit. The increasing demand for security means the increasing demand for more effective and efficient security policymaking. In other words, a governance approach is needed on security to be able to make a series of efforts or mechanisms aimed at providing strategic direction, coordinating interests and managing a security policy responsibly and properly.

In an institutional perspective, an organization is used to serve common interests and encourage cooperation so that the results obtained are more effective. ${ }^{13}$ For this reason, $\mathrm{SCO}$ is trying to analyze security threats that continue to grow each year and try to handle them. So that governance of cooperation based on geographic and functional specialization among state and non-state actors is able to provide national and international security. ${ }^{14} \mathrm{~A}$ series of security cooperation has been carried out such as joint military training in peace missions, information exchange, and cooperation with other international organizations. The perspective on seeing security was expanded along with the increasing development of international terrorism and drug trafficking that became a source of funding for international terrorism activities.

The development of the chain of terrorism and international drug trafficking has impacts on the security of Eurasia region. It was seen since the withdrawal of NATO forces in Afghanistan in 2014. In an official speech of announcing about the joining of India and Pakistan in the SCO in June 2017, SCO countries stressed the importance of the situations in Afghanistan for regional stability. SCO supported the

\footnotetext{
${ }^{13}$ Kirchner, Emil J., and Roberto Domínguez. "Regional organizations and security governance." In The Security Governance of Regional Organizations, Routledge, 2011

${ }^{14}$ Krahmann, Elke. "Conceptualizing Security Governance." Journal of the Nordic International Studies Association 38, no.1 (2003): 5-26.
} 
return of the SCO-Afghanistan Contact Group that had stalled to promote the restoration of peace in Afghanistan. ${ }^{15}$ Supported in Putin's speech saying that "The developments in Afghanistan are important for regional stability...". ${ }^{16}$ And Xi Jinping "... calls to all parties to support the country's peace and reconciliation process."17

Central Asia has long been the area of drug trafficking and transit routes to China, Russia, Pakistan, India, and the world. This situation is exacerbated by the increasing situation of neighboring Afghanistan, as the world's largest producer of opium and heroin. Central Asia share borders with Afghanistan for 1300 miles and share borders with Russia for 4000 miles. Difficulties in controlling broad borders affect the increase in drug trafficking in the Eurasia region. ${ }^{18}$ Furthermore, this drug trafficking is a source of work for transnational crime syndicates in the region. Which means that the increasing circulation of illegal drugs is likely to be directly proportional to the increase in terrorism, separatism, and externalization. Below is a map of the distribution of heroin from Afghanistan to several neighboring countries. ${ }^{19}$

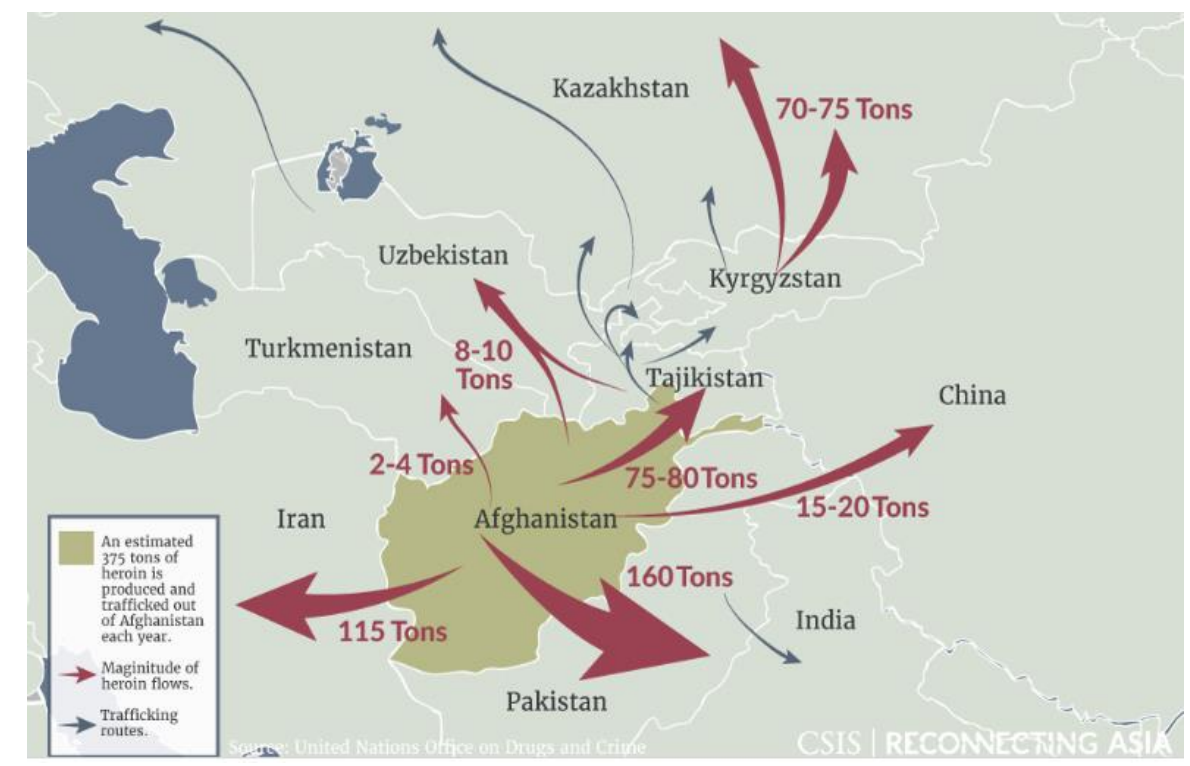

Figure 1: The Distribution Map of Heroin from Afghanistan ${ }^{20}$

\footnotetext{
15 The Shanghai Cooperation Organization. "The Astana declaration of the Heads of State of the Shanghai Cooperation Organisation." 2017.

${ }^{16}$ Putin, Vladimir. "Speech at the SCO Meeting in Expanded Format." Last modified Juni 9, 2017. http://en.kremlin.ru/events/president/transcripts/54739

${ }^{17}$ Xinhuanet. "Full text of Chinese President Xi's Speech at 17th SCO Summit." Last modified Juni 9, 2017. http://news.xinhuanet.com/english/2017-06/09/c_136353884.htm

${ }^{18}$ Reconnecting Asia. "Diagnosing Central Asia’s Drug Problem." Last modified Maret 7, 2017. https://reconnectingasia.csis.org/analysis/entries/diagnosing-central-asias-drug-problem/ 19 ibid.

20 ibid.,
} 
In addition to the drug trafficking, the number of attacks and victims of terrorism in the region has also increased since 2004. In the graph obtained from the Global Terrorism Database in Our World Data (2018) below (graph 2.) shows the number of fatalities from terrorist attacks both victims and perpetrators collected by region in the last 40-50 years to the year $2016^{21}$. Seen in the graph, the range from 2010 to 2016 there was a fairly high increase compared to the previous year against the number of victims from terrorist attacks. Although there was a downward trend at the end of the chart, the trend of victims from terrorist attacks remained high from the previous year. And Central Asia has a fairly high impact on the graph. ${ }^{22}$

Based on Our World in Data (2018) before, in 2016 there were around 75\% of related fatalities in the Middle East \& Africa, below a quarter of those in South and Southeast Asia, around one percent in Europe, and less than $0.5 \%$ in America ${ }^{23}$.

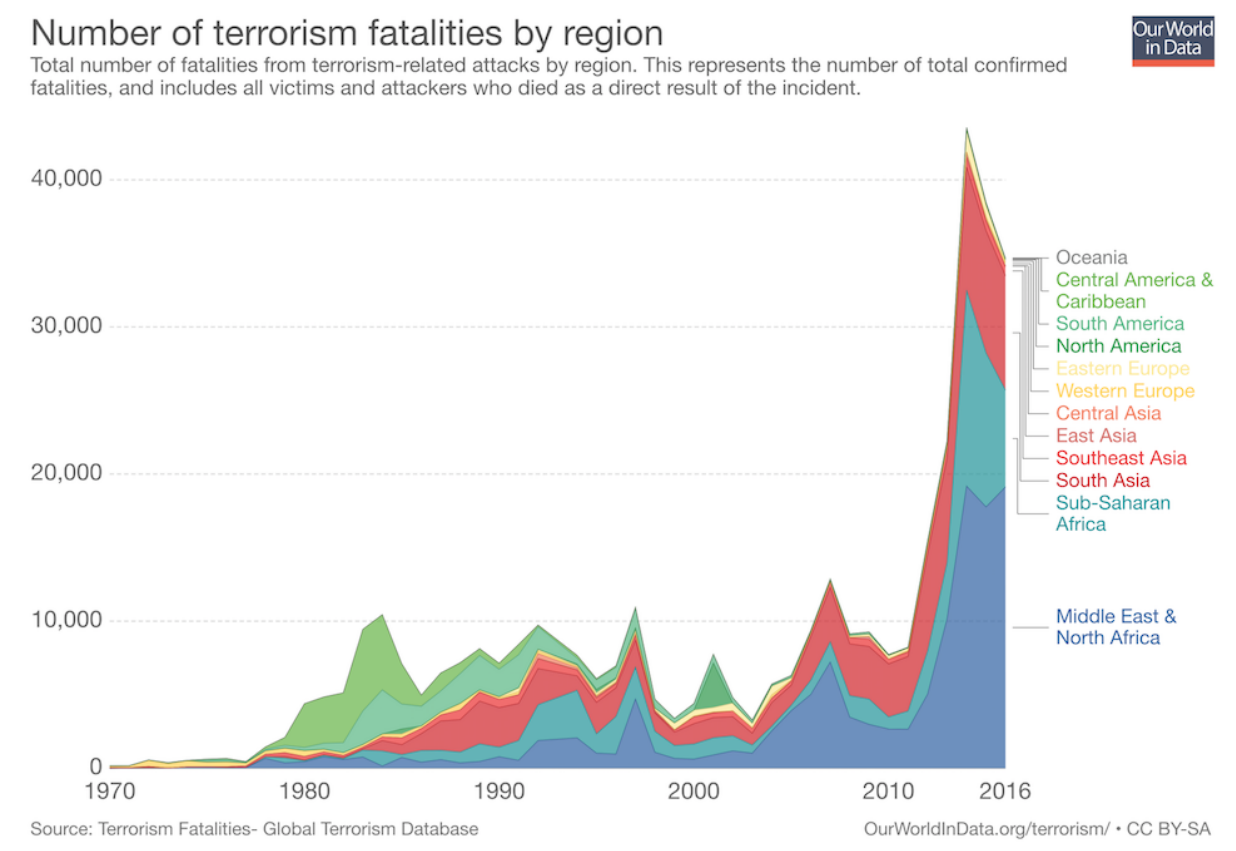

Figure 2: Number of Terrorism Fatalities by Region ${ }^{24}$

Central Asia has indeed become a fertile area for extremist activities such as the East Turkestan Islamic Movement (ETIM), the Islamic Movement of Uzbekistan (IMU) and others. Based on Global Risk Insights (2018), the most worrying is that over the past five years around 4,000 Central Asians have reportedly traveled to the Middle

\footnotetext{
${ }^{21}$ Our World in Data. "Terrorism".

${ }^{22}$ Ibid.,

${ }^{23}$ Ibid.,

${ }^{24}$ Ibid.
} 
East to join terrorist groups. ${ }^{25}$ It cannot be separated from the relationship between the Uighur separatist movement in China, Al-Qaeda, the Islamic Movement of Uzbekistan, Pakistan's Tehrik-i-Taliban and others. Based on Al-Jazeera (2016) in The Jamestown Foundation (2017) mention that Uighurs is part of Al-Nusrah in Central Asia. ${ }^{26}$

In other words, increasing of in international terrorist groups such as those in Syria, Afghanistan and even Pakistan and India influence the development of Eurasia terrorism because it's interconnection with each other. It is not surprising if China, Russia, and Central Asian countries, even India and Pakistan are trying to help Afghanistan stabilize the country. China even gave assistance to combat in Pakistan and India in order to suppressed the terrorism in Afghanistan. This is because the development of terrorism in India and Pakistan cannot be separated from terrorism in Afghanistan. Several terrorist groups originated from India and Pakistan before they spread to China, Central Asia, and Russia. At the CSTO Summit (The Collective Security Treaty Organization) the President of Tajikistan Emomali Rahmon warned that: "the specter of emergencies and security threats in the region is not diminishing, and could even grow". In addition, in a speech, Putin said that: "The risk of terrorism and extremist organizations makes incursions into countries neighboring Afghanistan have increased". 27

In addition to their relationship with the complexity of transnational crime such as drug trafficking and regional terrorist networks, and their involvement in efforts to assist the situation in Afghanistan and its experience in combating transnational crime, India and Pakistan are also met the requirement to become SCO member. By looking at the open nature of SCO; conformity with article 13 of the SCO Charter dated June 7, 2002, concerning rules for criteria and conditions of membership; and equality of vision and mission in dealing with terrorism, separatism, extremism; India-Pakistan can be the member of the SCO. In article 13, countries that wish to join SCO must be in the Euro-Asia region, have diplomatic relations with all

\footnotetext{
${ }^{25}$ Global Risk Insights. "The evolving terrorist threat to China’s Central Asia projects." Last modified Januari 22, 2018. https://globalriskinsights.com/2018/01/china-central-asia-serb-projects-terrorismrisk/

${ }^{26}$ The Jamestown Foundation. "The Uighurs and China's Regional Counter-Terrorism Efforts". Last modified Agustus 15, 2017. https://jamestown.org/program/the-uighurs-and-chinas-regional-counterterrorism-efforts/

${ }^{27}$ The Diplomat. "Central Asian States Among Countries Least Impacted by Terrorism". Last modified November 18, 2015. https://thediplomat.com/2015/11/central-asian-states-among-countries-leastimpacted-by-terrorism/
} 
SCO member countries, have status observers or partners in dialogue at the SCO, support trade-economic and humanitarian relations, not be under sanctions United Nations or in a state of armed conflict. ${ }^{28}$

Besides having the ability to maintain regional stability, India and Pakistan have also fulfilled the requirements to become SCO members as well. The SCO General Secretariat, Rashid Alimov, said that India and Pakistan have been observers for 12 years and have a wealth of experience in combating international security threats. So that India and Pakistan will be able to help the SCO's role in maintaining the stability and security of the Eurasia region. At the SCO summit in Astana 2017, President Xi Jinping, Putin, and Central Asian Countries, also stressed that security is important for development and the entry of India and Pakistan as members, will increase the influence of SCO in regional security. ${ }^{29}$ Because of transnational threats really need coordination and interdependence together. The joining of Pakistan will make efforts more effective and efficient to deal with increasing regional security threats.

\section{Identification of Regionalism through Case Studies of Expanding Membership of India and Pakistan in SCO}

Today regions have become a major part of the international world order. Region is a group of countries that have a geographical proximity and are interdependent. ${ }^{30}$ The importance of the regions themselves cannot be separated from the growth of regional cooperation that increasingly enlivens the dynamics of the development of regionalism that occupies an important position in the discourse on international relations. Regions refer to the concept of regionalism that is a policy and project where state and non-state actors cooperate in a particular area. ${ }^{31}$ Fawcett (2004) reveals that the purpose of regionalism is to pursue and promote shared goals in one or more issue areas ${ }^{32}$. In the context of peace and security, one of the aims of

\footnotetext{
${ }^{28}$ Trend News Agency. "SCO Member-Countries Heads Approve Regulations on Admission of New Members." Last modified Juni 11, 2010. https://en.trend.az/azerbaijan/politics/1703489.html (accessed Maret 30, 2018).

${ }^{29}$ The Shanghai Cooperation Organization. "Rashid Alimov: SCO Agenda is An Agenda for RegionWide Development." Last modified Desember 19, 2017. http://eng.sectsco.org/news/20171219/367739.html

${ }^{30}$ Fawcett, Louise, and Andrew Hurrell. Regionalism in World Politics: Regional Organization., Oxford: Oxford University Press, 1995.

${ }^{31}$ Ibid.

${ }^{32}$ ibid.,
} 
the establishment of regionalism is to prevent and control conflict in facing the challenges of globalization through regional responses. ${ }^{33}$ Many countries prefer to face security challenges in this era of globalization through its regional response.

Institutionalization or cooperation is an advanced stage of the development of activity in a region. Each region has its own characteristics that will affect the level of institutionalization or cooperation. SCO is a picture of regionalism in Central Asia. Based on Allison (2004) in Safiullin (2010) there are two different types in Central Asian regionalism. First, regionalism is defined by geography, typology, and geology that show political posture. While the second, regionalism as a state-led endeavor that is mainly here driven by China is represented through $\mathrm{SCO}^{34}$. The state-led endeavor here means trying to achieve more the interests and increase the strength of the largest and strongest members - China and Russia in the SCO. Safiullin (2010) also mentions that the SCO is a representation of the security regionalization process in Central Asia. ${ }^{35}$ Whereas Aris (2011) states that SCO is a representative of Eurasia regionalism ${ }^{36}$.

However, SCO which is referred to as Central Asian or Eurasia regionalism is different from the characteristics of regionalism which has many similarities in politics, social, regional location, customs and so on. As expressed by Fawcett (2004) and Fawn (2009) that regionalism is closely related to regions where there are groups of countries working together on elements of geographical proximity, background, history to equality of interests in a particular region. For example, the EU is regionalism in Europe whose member countries are in the European region and have the same political-economic system or ASEAN which is regionalism in Southeast Asia whose member countries are in the Southeast Asia region and despite having different political systems but having the same colonialism experience. Uniquely SCO is in a wide region and different entities, namely Russia in Eastern Europe; Kazakhstan, Kyrgyzstan, Tajikistan, and Uzbekistan in Central Asia; and China in East Asia. In addition, SCO countries have large differences in ideology, culture and the level of economic development.

\footnotetext{
${ }^{33}$ Fawn, Rick. " 'Regions' and their study: Wherefrom, what for and whereto?'." Review of International Studies 35 (2009): 5-34.

${ }^{34}$ Safiullin, Askhat. "The Shanghai Cooperation Organization and Security in Post-Soviet Central Asia." Journal of International and Security Studies 11, no. 4 (2010): 41-57.

${ }^{35}$ Ibid.,

${ }^{36}$ Aris, Stephen. Eurasian Regionalism: The Shanghai Cooperation Organisation. United Kingdom: Palgrave Macmillan, 2011
} 
Some literature argues that the growth of regionalism in an area depends on the characteristics of the region. Like, the EU is regionalism that begins with economic cooperation. Awareness of the importance of economic aspects in European countries is characteristic of regionalism. ${ }^{37}$ ASEAN is regionalism in Southeast Asia that has members that geographically located in the Southeast Asian region and the equality of members through the principle of non-intervention, consensus, and compromise bringing together ASEAN countries ${ }^{38}$. Poon (2001) who revealed that regionalism in the Asia Pacific is characterized by a regime development process that is centered on the development of ideas, business, and networks between state and private actors without the need to build an institution ${ }^{39}$. Or Byeong-hae (2004) that addresses regionalism in East Asia is characterized by its inclusion in a new phase of intra-regional trade integration with increasing trade intensity since the $1990 \mathrm{~s}^{40}$

As explained earlier, SCO is referred to as Central Asia regionalism that leads to the State-led endeavor because there are two superpower countries, China and Russia. Or referred to as Eurasia regionalism because of the location of its members in Central Asia, East Asia, and Eastern Europe. The regionalism represented by SCO, from the very beginning, was marked by security cooperation and conflict resolution along the Eurasia region. While India and Pakistan are SCO member, they actually reside in the region of South Asia. It is known that until now South Asia has difficult to form a regional organization that capable to regulate the region because South Asia is less stable. Compared to the EU in Europe, ASEAN in Southeast Asia, or regionalism in the Asia Pacific and East Asia, SCO's state entities exist in many regions, namely Central Asia, East Asia, South Asia, and Eastern Europe. Although regionalism is based on the proximity of the region as well as the closeness of the region between India and Pakistan and SCO, it is still different because it is unfounded from the same region, even consisting of 4 regions.

Then, regarding membership expansion, the expansion of EU membership with Baltic countries such as Estonia, Latvia and Lithuania aim to be important for the

\footnotetext{
${ }^{37}$ Nuraeni, Deasy Silvya, and Arifin Sudirman. Regionalisme dalam Studi Hubungan Internasional [Regionalism in the Study of International Relations]. Yogyakarta: Pustaka Pelajar, 2010.

${ }^{38}$ Seah, Daniel. "The ASEAN Charter." The International and Comparative Law Quarterly 58, no. 1 (2009): 197-212.

${ }^{39}$ Poon, Jessie P H. "Regionalism in the Asia Pacific: is Geography destiny?" Area 33, no. 3 (2001): 252-260.

${ }^{40}$ Byeong-hae, Sohn. "Towards A New Regionalism in East Asia." Journal of Economic Integration 19, no. 3 (2004): 499-518.
} 
progress of the EU. Such as, the application of immigration and asylum policies to combat illegal immigration and the development of asylum laws in accordance with EU principles. ${ }^{41}$ In ASEAN, the expansion of membership such as the entry of Laos and Vietnam goes hand in hand with the shared interests of resolving the conflict in Cambodia so that the region can be stable for economic and political cooperation. ${ }^{42}$ In SCO, expanding membership is also aimed at maintaining and strengthening regional security from threats. Moreover, the nature of the threat is transnational and related to the security of other countries. But the difference here is that other regional organizations are expanding for countries within the region and for the region. While SCO is only based on mutual interests and regional security.

The membership expansion can also be seen from several perspectives such as the expansion of the EU into Eastern Europe can be seen through an institutional rational perspective because it is not only caused by actions that must be in accordance with EU principles but the exchange of interests and profit maximization. ${ }^{43}$ Or Sienkiewicz $(2003)^{44}$ and Naabers $(2002)^{45}$ who see the expansion of the EU through a constructivist perspective that emphasizes that community, values, identity, and dialogue are important in European regionalism and its expansion into Eastern Europe. Or ASEAN that is seen through institutional liberals where the organization becomes a means to establish mutual trust and the community resolves conflicts. Like the entry of Laos and Vietnam, which entered together with Cambodia in order to form a stable area for joint cooperation.

The SCO in seeing membership expansion is more suitable to be seen using an institutional liberal perspective. Because of SCO is a regional organization in the region that has become a place to fight regional threats. So that SCO as an organization is able to establish trust among its members to cooperate. As seen that SCO has the member countries that can be said to be unequal. China and Russia are

\footnotetext{
${ }^{41}$ Elson, Amy L. "Baltic State Membership in the European Union: Developing a Common Asylum and Immigration Policy." Indiana Journal of Global Legal Studies 5, no. 1 (1997): 317- 340.

42 Amer, Ramses. "Conflict Management and Constructive Engagement in ASEAN's Expansion." Third World Quarterly 20, no. 5 (1999): 1031-104

${ }^{43}$ Piedrafita, Sonia, and José I. Torreblanca. "The Three Logics of EU Enlargement: Interests Identities and Arguments." Politique Européenne, no. 15 (2005): 29-59.

${ }^{44}$ Sienkiewicz, Aldona. "The European Union's Enlargement to the East: Can a Constructivist Perspective Explain Integration in Europe?" Glendon Journal of International Studies (2003): 114-124.

${ }^{45}$ Nabers, Dirk. "The Social Construction of International Institutions - ASEAN+3 and the Eastern Enlargement of the European Union." Workshop on Asia-Pacific Studies in Australia and Europe: A Research Agenda for the Future (2002).
} 
member countries that have higher economic, political and military capabilities than the Central Asian countries. Especially, after the entry of India and Pakistan which are also developed countries. Therefore, SCO has four countries that have nuclear power and large economic developments, namely China, Russia, India, and Pakistan. Whereas both Central Asia and Russia are countries that rich in energy. In addition, the history and relations of China, Russia, India, and Pakistan were marked by power competition and influence. SCO is the one that unites them with the same interests, namely fighting security threats.

Based on the form of regionalism, the expansion of membership, and the way of looking at the expansion it can be concluded that each existing regionalism has different characteristics and can be seen its continuity from a different perspective. However, the those still have the same element as expressed by Nuraeni, Silvya and Sudirman (2017) to recognize the growing regionalism in the region can be seen through a process of interaction that takes place between state and non-state actors and uses a theoretical approach in understanding the sustainability of regionalism ${ }^{46}$. In SCO, its members have a different history, different power, complex relationships, and different regions. The interaction process takes place based on shared interests, namely the threat of regional security from terrorism, separatism, extremism and drug trafficking which is increasing due to the influence of the situation in that is still establishing their stability. SCO as a Eurasia regional organization provides a place for all members to establish a joint trust so that cooperation based on the interests of regional security can be achieved.

\section{Conclusion}

Regionalism in SCO has a different character and can identify through how SCO accepts membership of India and Pakistan. The approval of India and Pakistan's membership in the SCO is based on pragmatic interests between SCO member countries in an effort to maintain regional security. SCO sees that transnational terrorism, separatism, extremism, and drug trafficking require cooperation with other countries. Besides that, India and Pakistan are in the complexity of the SCO regional security. Especially after NATO's withdrawal from Afghanistan has increased regional security threats. With the entry of India and Pakistan in the SCO, it will

\footnotetext{
${ }^{46}$ Nuraeni, Deasy Silvya, and Arifin Sudirman. Regionalisme
} 
facilitate cooperation, information exchange, and joint capacity building to make counter-terrorism more effective so that regional security and stability can be created. The SCO in Eurasia Regionalism has a special characteristic, as long as it has the same goal of maintaining regional security, regionalism can still occur even though different state entities in the region, different histories, different political and economic conditions, and so on. 


\section{Bibliography}

Allison, Roy. "Regionalism, Regional Structures and Security Management in Central Asia." International Affairs 80, no. 3 (2004): 463-483.

Amer, Ramses. "Conflict Management and Constructive Engagement in ASEAN's Expansion." Third World Quarterly 20, no. 5 (1999): 1031-1048

Aris, Stephen. Eurasian Regionalism: The Shanghai Cooperation Organisation. United Kingdom: Palgrave Macmillan, 2011.

Byeong-hae, Sohn. "Towards A New Regionalism in East Asia." Journal of Economic Integration 19, no. 3 (2004): 499-518.

Council on Foreign Relation. "The Shanghai Cooperation Organization". Last modified October 14, 2015. https://www.cfr.org/backgrounder/shanghaicooperation-organization

Elson, Amy L. "Baltic State Membership in the European Union: Developing a Common Asylum and Immigration Policy." Indiana Journal of Global Legal Studies 5, no. 1 (1997): 317- 340.

Fawcett, Louise. "Exploring Regional Domains: A Comparative History of Regionalism." International Affairs 80, no. 3 (2004): 129-440

Fawcett, Louise, and Andrew Hurrell. Regionalism in World Politics: Regional Organization., Oxford: Oxford University Press, 1995.

Fawn, Rick. " 'Regions' and their study: Wherefrom, what for and whereto?'." Review of International Studies 35 (2009): 5-34.

Global Risk Insights. "The evolving terrorist threat to China's Central Asia projects." Last modified Januari 22, 2018. https://globalriskinsights.com/2018/01/chinacentral-asia-serb-projects-terrorism-risk/

Kirchner, Emil J., and Roberto Domínguez. "Regional organizations and security governance." In The Security Governance of Regional Organizations, Routledge, 2011

Krahmann, Elke. "Conceptualizing Security Governance." Journal of the Nordic International Studies Association 38, no.1 (2003): 5-26.

Lanteigne, Marc. " "In Medias Res": The Development of the Shanghai Cooperation Organization as a Security Community." Pacific Affairs 79, no. 4 (2006/2007): 605-622.

Matveeva, Anna, and Antonio Giustozzi. "The SCO: A Regional Organization in The Making." Working Paper 39 (2008).

Mihslsche, Veronica. "Cooperation Vs. Competition in Central Asia." Challenges of the Knowledge Society Conference (2015).

Nabers, Dirk. "The Social Construction of International Institutions - ASEAN+3 and the Eastern Enlargement of the European Union." Workshop on Asia-Pacific Studies in Australia and Europe: A Research Agenda for the Future (2002).

Nuraeni, Deasy Silvya, and Arifin Sudirman. Regionalisme dalam Studi Hubungan Internasional [Regionalism in the Study of International Relations]. Yogyakarta: Pustaka Pelajar, 2010.

Our World in Data. "Terrorism". Last modified Januari, 2018. https://ourworldindata.org/terrorism\#terrorism-in-specific-countries-andregions

Panda, Jagannath P. "Beijing's Perspective on Expansion of the Shanghai Cooperation Organization: India, South Asia, and the Spectrum of Opportunities in China's Open Approach." Asian Perspective 36, no. 1 (2012): 493-530. 
Piedrafita, Sonia, and José I. Torreblanca. "The Three Logics of EU Enlargement: Interests Identities and Arguments." Politique Européenne, no. 15 (2005): 2959.

Poon, Jessie P H. "Regionalism in the Asia Pacific: is Geography destiny?" Area 33, no. 3 (2001): 252-260.

Putin, Vladimir. "Speech at the SCO Meeting in Expanded Format." Last modified Juni 9, 2017. http://en.kremlin.ru/events/president/transcripts/54739

Reconnecting Asia. "Diagnosing Central Asia's Drug Problem." Last modified Maret 7, 2017. https://reconnectingasia.csis.org/analysis/entries/diagnosing-centralasias-drug-problem/

Safiullin, Askhat. "The Shanghai Cooperation Organization and Security in PostSoviet Central Asia." Journal of International and Security Studies 11, no. 4 (2010): 41-57.

Seah, Daniel. "The ASEAN Charter." The International and Comparative Law Quarterly 58, no. 1 (2009): 197-212.

Sienkiewicz, Aldona. "The European Union's Enlargement to the East: Can a Constructivist Perspective Explain Integration in Europe?" Glendon Journal of International Studies (2003): 114-124.

The Diplomat. "Central Asian States Among Countries Least Impacted by Terrorism". Last modified November 18, 2015.

https://thediplomat.com/2015/11/central-asian-states-among-countries-leastimpacted-by-terrorism/

The Hindu. "Fresh initiatives in SCO expansion." Last modified Maret 23, 2010. http://www.thehindu.com/todays-paper/tp-opinion/Fresh-initiatives-in-SCOexpansion/article16590257.ece

The Jamestown Foundation. "The Uighurs and China's Regional Counter-Terrorism Efforts". Last modified Agustus 15, 2017. https://jamestown.org/program/theuighurs-and-chinas-regional-counter-terrorism-efforts/

The Shanghai Cooperation Organisation. "About SCO". http://eng.sectsco.org/about_sco/

The Shanghai Cooperation Organization. "Rashid Alimov: SCO Agenda is An Agenda for Region-Wide Development." Last modified Desember 19, 2017. http://eng.sectsco.org/news/20171219/367739.html

The Shanghai Cooperation Organization. "The Astana declaration of the Heads of State of the Shanghai Cooperation Organisation." 2017.

Trend News Agency. "SCO Member-Countries Heads Approve Regulations on Admission of New Members." Last modified Juni 11, 2010.

https://en.trend.az/azerbaijan/politics/1703489.html (accessed Maret 30, 2018).

Xiaodong, Zhao. "The Shanghai Cooperation Organisation and Counter-Terrorism Cooperation." ASIA Paper (2012).

Xinhuanet. "Full text of Chinese President Xi's Speech at 17th SCO Summit." Last modified Juni 9, 2017. http://news.xinhuanet.com/english/201706/09/c_136353884.htm

Yuqun, Shao. "Intra-SCO Security Cooperation Helps Regional Stability." Last modified September 17, 2014. https://www.chinausfocus.com/peacesecurity/intra-sco-security-cooperation-helps-regional-stability 